Article

\title{
The Unexpected Negotiator at the Table: How the European Commission's Expertise Informs Intergovernmental EU Policies
}

\author{
Meng-Hsuan Chou $^{1}$ and Marianne Riddervold ${ }^{2, *}$ \\ ${ }^{1}$ Public Policy and Global Affairs Programme, School of Humanities and Social Sciences, Nanyang Technological \\ University, 637332 Singapore, Singapore; E-Mail: hsuan@cantab.net \\ ${ }^{2}$ ARENA Centre for European Studies, University of Oslo, 0318 Oslo, Norway; \\ E-Mail: marianne.riddervold@arena.uio.no \\ * Corresponding author
}

Submitted: 4 June 2014 | In Revised Form: 12 September 2014 | Accepted: 14 October 2014|

Published: 31 March 2015

\begin{abstract}
How, if at all, does the Commission's expertise inform intergovernmental decision-making within the EU? In this article, we aim to capture the relationship between the Commission's expertise and its influence within intergovernmental policy-areas through a study of Commission influence in two least likely sectors: security and defence policies (military mission Atalanta and EU Maritime Security Strategy) and external migration (EU mobility partnerships with third countries). In these cases we observe that the Commission strongly informs policy developments even though it has only limited formal competences. To explore whether and, if so, how this influence is linked to its expertise, we develop and consider two hypotheses: The expert authority hypothesis and the expert arguments hypothesis. To identify possible additional channels of influence, we also consider the relevance of two alternative hypotheses: The strategic coalition hypothesis and the institutional circumvention hypothesis. We find that the Commission's use of its expertise is indeed key to understanding its de facto influence within policy-areas where its formal competences remain limited. Our findings add to the existing literature by revealing how expertise matters. Specifically, our cases show that the Commission informs intergovernmental decision-making by successfully linking discussions to policy-areas where it holds expert authority. However, the Commission also informs EU policies by circumventing the formal lines of intergovernmental decision-making, and by cooperating with member states that share its preference for further integration.
\end{abstract}

\section{Keywords}

argument-based learning; bargaining; EU; European Commission; expert knowledge; expertise; foreign policy; influence; institutional circumvention; institutionalism; intergovernmental policies

\section{Issue}

This article is part of the special issue "The Role of Expert Knowledge in EU Executive Institutions", edited by Professor Åse Gornitzka (University of Oslo, Norway) and Dr. Cathrine Holst (University of Oslo, Norway).

(C) 2015 by the authors; licensee Cogitatio (Lisbon, Portugal). This article is licensed under a Creative Commons Attribution 4.0 International License (CC BY).

\section{Introduction}

This article explores the relationship between expertise and the European Commission's influence on outcomes in European Union's (EU) formally intergovernmental issue-areas. We start from the observation that despite de jure having only limited competence in these domains, a growing number of studies suggest that, de facto, the Commission increasingly informs their decisionmaking-in security, defence, migration, and education (Gornitzka, 2009; Jørgensen, Oberthür, \& Shahin, 2011; Riddervold \& Sjursen, 2012). Other studies tell us that unpacking the ways in which international bureaucracies use their "expert knowledge" may hold the key to un- 
derstanding their impact on policy outcomes (Barnett \& Finnemore, 1999, 2004; Checkel, 2001; Copeland \& James, 2014; Cross, 2010; Haas, 1992; Hooghe, 2005; Joerges \& Neyer, 1997; Martens, 2008). Yet whether, and, if so, how, the Commission's observed influence on formally intergovernmental policies is linked to its expertise remains unexplored in the literature. This is puzzling because, as Hooghe $(2001$, p. 7) argues, the Commission is "a body of unelected officials appointed for their expertise" (emphasis added). In Community policy-areas where it has competence, Commission expertise is a wellestablished indicator of why it has been able to successfully propose new regulatory measures. Hence, our research question is: How, if at all, does the Commission's expertise inform intergovernmental decision-making?

To tease out how the Commission's expertise putatively influences formally intergovernmental EU policies, we develop and operationalise two hypotheses. The first, the expert authority hypothesis, builds on sociological institutionalist role theory and suggests that the European executive may influence EU policies by linking intergovernmental discussions to policy-areas where it holds expert authority (Barnett \& Finnemore, 2004; Elgstrøm \& Smith, 2006). The second, the expert arguments hypothesis, builds on communicative action theory and suggests that the Commission may influence member states' decisions by presenting convincing expertise-based arguments (Eriksen, 2005; Riddervold, 2011; Risse, 2000; Sjursen, 2004). We apply them to study the Commission's influence in two least likely sectors: security and defence policies (the cases of Atalanta military mission and EU Maritime Security Strategy, EUMSS), and external migration policies (EU mobility partnerships). In these cases, the European executive's formal competences are limited, but it is seen to be strongly informing policy outcomes. We expect both hypotheses to contribute to capturing its ability to penetrate sectors and decision-making processes where we would not ordinarily anticipate a strong Commission impact. It may also be that, however, the Commission's influence is linked to other factors than its expertise. To control for this possibility, we consider the relevance of two alternative hypotheses: the strategic coalition-building hypothesis and the institutional circumvention hypothesis. By examining the relevance of these four analytically distinct, yet empirically overlapping, hypotheses, we seek to offer a more comprehensive understanding of the relationship between Commission expertise and its influence in intergovernmental EU policies. In so doing, we also aim to provide an improved understanding of the different functions of expertise in EU decision-making processes, more generally, and the Commission's role within European intergovernmental policymaking, more specifically.

This article is organised as follows. First, we develop and operationalise two hypotheses concerning how the Commission may putatively use its expertise to influ- ence EU intergovernmental policymaking before presenting the two alternative hypotheses. Second, we show how the Commission's de facto influence over EU intergovernmental decisions exceeds its formal competence in security, foreign and external migration policyareas. Third, we analyse how the observed influence may be explained by considering the relevance of our four hypotheses. We conclude by discussing our overall findings and their implications for studies of Commission expertise and EU intergovernmental policies.

\section{How Can the Commission Influence through Its Expertise?}

There is a rich literature in both international relations and EU studies that examine the linkage between nongovernmental actors' expert knowledge and their influence in international policymaking (cf. Barnett \& Finnemore, 2004; Busch \& Liese, 2014; Elgström \& Smith, 2006; Joerges \& Neyer, 1997). Most of this literature assumes that all actors, regardless of their institutional affiliation, are rational and capable of adapting to changing situations. What differ in their assumptions are the explanatory mechanisms involved in this change process. Based on these studies, we develop two hypotheses concerning how the European executive may influence intergovernmental decisions through its expertise: (1) influence by evoking the role of expert authority (expert authority hypothesis), and (2) influence by presenting convincing expert arguments (expert arguments hypothesis).

The expert authority hypothesis builds on the insights of sociological institutionalist role theory. Here, roles refer to "patterns of expected or appropriate behaviour" (Elgstrøm \& Smith, 2006, p. 5) or "those expectations that other actors (alter) prescribe and expect the role-beholder (ego) to enact" (Kirsten \& Maull, 1996, cited in Aggestam, 2006, p. 18). Put simply, roles define expectations according to behaviour in line with March and Olsen's (1998) "logic of appropriateness". It follows that one would expect that "actors seek to fulfil the obligations encapsulated in a role, an identity, a membership in a political community or group, and the ethos, practices and expectations of its institutions" (March \& Olsen, 2006, p. 689). Building on this perspective, the decision-makers' expectations of the Commission's role would determine the influence it is able to exercise. If a particular issue is defined or treated as intergovernmental, the corresponding expectation of the Commission's role or appropriate behaviour would be that its involvement should be limited.

The EU is, however, a complex institution. This complexity suggests that, if a different role-expectation is introduced, the Commission's room for manoeuvre in intergovernmental settings could increase. In particular, we suggest that the European executive could expand its capacity to act across intergovernmental issue- 
areas if the role it plays in Community policy-areas (i.e., those at the heart of creating the Single Market) is evoked. This is because, within Community policyareas, the Commission is the recognised and acknowledged authority; its particular involvement and influence in policymaking are taken for granted (Barnett \& Finnemore, 2004). Hooghe (2001) tells us that the Commission suggests, controls, and manages policy developments in the various policy-areas its departments and services (Directorates-General, DGs) cover. On this basis, we expect that the Commission may influence EU intergovernmental decisions if its "Community expert authority" is successfully evoked when the intergovernmental issues under discussion are linked with those in which it has Treaty competence. If successful, we would observe changes in the policymakers' expectations of its involvement: instead of playing an outsider's role, the European executive would be expected to enact its "normal" role as the competent policy initiator and guardian of the Treaties.

Analytically, our expert authority hypothesis is akin to Rittberger's (2012) hypothesis of the Lisbon Treaty's empowerment of the European Parliament. He argues that the introduction of qualified-majority voting automatically led member states to accept Parliamentary involvement in policymaking: When applying particular decision-making procedures, the Parliament should play its role of co-decision-maker. Similarly, our expert authority hypothesis anticipates that linking an intergovernmental issue area (e.g., security) to Community policy-areas would lead to the acceptance of Commission participation and influence over such decisionmaking. Following Rittberger (2012), we would expect to observe the following if the expert authority hypothesis is valid: (1) Commission proposals or suggestions would be linked to existing Community policy-areas; (2) Commission involvement in decision-making would not be contested; and (3) Commission proposals and suggestions would be adopted more or less automatically, i.e., with "little justification but also hardly any articulation" (Rittberger, 2012, p. 32). When this role is activated through referencing Community issues, the member states are more inclined "to copy what the Commission says and does" (Martens, 2008, p. 637).

In new policymaking situations, however, studies find that there is often little opportunity in practice for copying, role-enactment or institutionalised behaviour (cf. Checkel, 2001; Eriksen \& Fossum, 2000; Risse, 2000; Rittberger, 2012). When facing new developments that have not previously been discussed nor regulated the EU-level, such as defence or environmental issues, there is less certainty about which norms and roles should apply. Thus, instead of mimicking earlier behaviour or drawing on established role-expectations, decisionmakers "have to figure out the situation in which they act, apply the appropriate norms, or choose among conflicting rules" (Risse, 2000, p. 6). As Rosén (2014, p.
4) notes, norms have to be activated in order to have an impact on decision-making. We know that in Council meetings where foreign policies are discussed, European policymakers present and assess norms and information before any action is taken (Lewis, 2011). Put simply, norms are not seen as given, but are instead articulated, justified, discussed, and evaluated.

Based on these insights, we suggest an additional hypothesis of how the Commission's expertise may putatively influence intergovernmental EU policies: The expert arguments hypothesis. This hypothesis builds on communicative action theory's basic assumption that decision-makers are communicatively rational, meaning that they have the ability to offer reasons for their positions and actions, and to assess reasons others give (Deitelhoff, 2009; Eriksen \& Fossum, 2000; Riddervold, 2011; Risse, 2000; Sjursen, 2004). When applying a communicative approach in descriptive or explanatory studies, there is thus an underlying assumption that actors are able to learn on the basis of arguments others present. Consequently, the arguments and reasons provided may lead to agreement on a given policy (Deitelhoff, 2009; Eriksen, 2005; Sjursen, 2004). As Eriksen and Fossum (2000, p. 257) put it: "Co-operation comes about when the process of reason-giving generates a capacity for change of viewpoints". Similarly, Sjursen (2004, p. 115) argues that it is through a communicative process in which arguments are rationally assessed and their relevance for policy decisions established. The arguments leading to agreements could refer to material gains, threats or promises as part of a bargaining game, but they could also refer to expert knowledge or different types of norms.

This perspective may be useful for understanding the European executive's influence because it allows us to specify a micro-mechanism through which Commission expertise may affect intergovernmental decisionmaking. The "explanatory power" of arguments, according to Eriksen (2005, p. 17), "is based on the motivational force of reason, namely, that insights into good reasons have behavioural consequences" (emphasis original). Specifically, we suggest that the Commission may exercise influence through the mechanism of argument-based learning: If it presents expertisebased arguments that (at least some of) the decisionmakers perceive as convincing and therefore change their positions accordingly (Riddervold, 2011). If the expert arguments hypothesis accounts for its influence in formally intergovernmental issue-areas, we expect to observe the following: (a) evidence of the European executive justifying its proposals by explaining them based on its expert knowledge; (b) evidence confirming that Commission arguments affected the decisionmakers' positions and thus the policies they eventually adopt. Indications of (b) could come in the form of learning: Decision-makers justifying their positions in a similar way as the Commission's position.

While our focus is on specifying the ways in which 
the Commission influences intergovernmental decisions through its expertise, we do not exclude the possibility that its expert knowledge may account for only a part, or even none, of the explanation. To control for this possibility, and thus tease out the extent to which expertise accounts for the influence observed, we also consider the relevance of two alternative hypotheses. We developed these hypotheses from two sets of mainstream literature in international relations and EU studies: rational-choice theory and institutionalist theory. The first alternative hypothesis - the strategic coalition hypothesis-stems from the well-known rationalchoice bargaining literature. It proposes that the Commission's capacity to influence intergovernmental policies may be due to its ability to build alliances with member states that share its preferences (cf. Pollack, 1997; Schmidt, 2001, p. 41; Tallberg, 2008).

The second alternative hypothesis - the institutional circumvention hypothesis-assumes that the Commission's ability to influence policy developments is linked to "opportunities and constraints in the internal and external environment" (Olsen, 2009, p. 25). More precisely, building on Egeberg (2006), we consider whether the Commission has exploited the unique EU organisational structure to informally bypass or "circumvent" the established intergovernmental decisionmaking structure. In instances of institutional circumvention, we expect that it may occur in at least two ways: (i) the Commission cooperates directly with national bureaucrats to indirectly influence the member states' positions (bureaucrats prepare national positions, but do not decide); or (ii) the Commission cooperates with other EU-level institutions (e.g., the military committee or the European External Action Service, EEAS) to affect EU intergovernmental policies. We treat all four hypotheses as complementary rather than as mutually exclusive in the analysis. The aim of these hypotheses is thus to help capture empirical realities, and their relevance may vary across the different cases.

Methodologically, we adopt an interpretative approach and seek to uncover the Commission's involvement and influence in three decision-making processes from the actors' perspective (Eliaeson, 2002, p. 52). To do so, we define influence in an inter-relational way to mean that the Commission has influence when evidence suggests that its interactions with other actors during the decision-making process affected the contents of EU policies or positions (Riddervold, 2015). The Commission's influence over policy outcomes may be strong or weak, short or long-term, direct or accumulative, but we consider these to be empirical questions. Our definition of influence is thus broader than the conventional understanding, where actor A's influence is linked to whether or not he/she can "cause" or implicitly coerce actor B to do something he/she would otherwise not have done (Dahl, 1957). Similarly, we define expertise widely to refer to both coordinative and practical "know-how" or "ways of doing things" and sector-specific, specialist knowledge (cf. Chou, 2012a). We define "influence" and "expertise" broadly to enable us to account for the empirical complexity of multi-level decision-making.

Our data for Atalanta and the EUMSS consists of 26 semi-structured interviews with participating actors, follow-up interviews (phone, email), and primary documents. We also obtained the different drafts of the Communication and the EUMSS (from 2012-2014), and observed some of the informal discussions between the Commission and member state officials in May 2014, prior to the Council's decision to adopt the Strategy. For EU mobility partnerships, we rely on 30 semistructured interviews carried out between September 2009 and August 2010, primary documents, and published studies. The majority of our interviewees agreed to speak only under the condition of anonymity. Hence, the interview data we use and quote in our cases contain the speaker's institutional affiliation and interview date (see Appendix). We rely primarily on the 56 interviews and we control for consistency by triangulating across different data sources: Between different actors and institutions involved in decision-making, between arguments and actual behaviour, and across the three cases. While our findings may reveal if and how expertise matters in accounting for the Commission's growing influence in some intergovernmental issue-areas, our limited case selection indicates that further studies are needed before any generalisation can be made.

\section{The Case of Security and Defence: The Atlanta Military Mission and EUMSS}

Decision-making on Atalanta and the EU Maritime Security Strategy formally falls under the framework of the EU's Common Security and Defence Policies (CSDP), which is "subject to specific rules and procedures" (Council of the European Union, 2012). Following these procedures, decision-making powers formally lie exclusively with the Council and its preparatory bodies; decisions are reached through unanimity following discussions among the member states' Permanent Representatives and its special foreign and security committee, the Political and Security Committee (PSC). Accordingly, the Commission has very limited formal decision-making powers in these two cases (Merket, 2012, p. 628). Indeed, within the CSDP, the Commission does not have monopoly of initiative, it cannot take cases of non-compliance to the European Court of Justice, and it has no budgetary powers over EU military missions. The European executive does not have formal connections with, or control over, the intergovernmental external action units in the new "EU foreign service", the EEAS (Thym, 2011, p. 16).

\subsection{Atalanta}

Launched in December 2008, Atalanta is the EU's first 
and still on-going naval operation and allows for the use of force to "contribute to the deterrence, prevention and repression of acts of piracy and armed robbery off the Somali coast" (Council of the European Union, 2008). As with all military EU operations, it is ad hoc, and any military contribution is voluntary for the member states.

Our interviewees revealed that the Commission was very much involved in the process leading to the launch of Atalanta. "They were in all the meetings" (NatDel\#4); "involved in the entire process...Meetings, correspondence, emails etc." (NatDel\#6). Moreover, rather than being a passive observer, the Commission "gains influence by sitting in on the meetings" (NatDel\#5). According to national delegates, NATO officials, and the Commission itself, it moreover had a particular impact on Atalanta through its legal and development instruments: It secured agreements with countries in the region for transferring suspected pirates (Interviews, 2010, 2013). This was crucial because such agreements were a necessary condition for Atalanta's launch. The member states did not want to bring the pirates to Europe out of fear that they might seek asylum, while at the same time they were concerned with securing their basic rights (Riddervold, 2014). The solution was to establish third country agreements, and such agreements could not be established without the Commission's involvement. As a national delegate put it: The member states needed "the expertise of DG DEVCO and...Justice" (NatDel\#1). Most importantly, by working with the Commission, the French Presidency could draw on its "financial instruments in order to push for a conclusion of these agreements...There were some benefits for the countries who signed...They got in return some financial support from the EU" (NatDel\#2).

But did the Commission use these financial instruments as a bargaining tool to influence Atalanta? The data does not support this hypothesis. Contrary to expectations following the bargaining hypothesis, we did not find that the Commission strategically log-rolled or threatened its way into the Atalanta decision-making process. Similarly, we did not find evidence to suggest that the Commission influenced the decision to launch Atalanta by cooperating directly with national ministries or officials from other EU institutions to circumvent the member states. Instead, we found the Commission's involvement was wanted by the member states and that it cooperated directly with the EU Presidency to realise an EU mission based on its expertise across the fields its DGs covered. As an EU parliamentarian interviewee argued, the Commission's increasing involvement in military missions at the informal planning phase "is also [based] on the expertise" (EP\#1). The Commission is involved because its competence in Community policy-areas makes it "able to advise, on what they could do and on the timing, and that can lead to some adjustments in the planning" (NatDel\#2).
It "has power through its competences and skills" (NatDel\#6), and, therefore, "they should be present and available for consultation" (NatDel\#1). Even within the CFSP "it is only the big member states [that]...can challenge the Commission's competence in some areas" (NatDel\#6). Summarising Commission involvement in intergovernmental decision-making nicely, a national delegate said: "Where CSDP Security stops and the Commission begin, there is an overlap...especially when it comes to rule of law" (NatDel\#4).

\subsection{EU Maritime Security Strategy}

The Council (2010) adopted its first Conclusions on an EU Maritime Security Strategy in April 2010. In December 2013, the European Council $(2013$, p. 4) tasked the EEAS and the Commission to present a joint communication on "an EU Maritime Security Strategy by June 2014". Published in March 2014, the Communication contained a list of maritime threats and suggested EU actions. The Greek Presidency, however, wanted its own paper; it introduced an informal text which the "Friends of the Presidency" group discussed six times before the General Affairs Council adopted the EUMSS in June 2014. While the text changed and some suggested actions removed, the main ideas remained.

The Commission's influence is clear in the EUMSS case. In 2010, the Council (2010) emphasised that preparation would occur within the CFSP/CSDP framework. Nonetheless, the Commission started drafting it with the EEAS in mid-2012, co-chairing regular meetings between them (Comm\#2-\#5; EEAS\#1, \#3)-18 months before the European Council tasked them to prepare the text. The Commission and the EEAS moreover were at all the "Friends of the Presidency" meetings, where they spoke and successfully proposed amendments (NatDel\#8; NatDel\#9).

In particular, we find that the Commission influenced the EUMSS in three central ways. First, it reframed the Strategy's scope so much that "the member states" intention was very different from what became the process and the outcome (Comm\#2). While the initial Council decision was for the EEAS to explore a military/security-focused EUMSS, the final Strategy was cross-sectoral, involving issues under the Community integrated maritime policy and other Community policy-areas (Comm\#1-\#5; EEAS\#1-\#3). Second, the Commission literally wrote the Communication which the member states revised and adopted, together with the EEAS. Eleven DGs contributed text (e-mail with EEAS\#1; EEAS\#3). Third, even though the EEAS formally led the intergovernmental EUMSS process, the Commission successfully introduced "the Commission policymaking procedures" for preparing the Communication (EEAS\#3). Consequently, the Communication was "not to be shared with the outside world, not even the member states, before it is fin- 
ished" (EEAS\#3), and all Commissioners had to sign the Communication before its official presentation to the Council and its underlying bodies, and the member states' adoption (Comm\#2; EEAS\#1; EEAS\#3). So, then, how can we account for the Commission's influence? How, if in any way, was it linked to its expertise?

Both expert hypotheses find support in the EUMSS case. First, the expert arguments hypothesis accounts for how the Commission was able to change the Strategy's scope in line with its preferences for crosssectoral maritime security policies. Our interviewees tell us that the more cross-sectoral, the wider the implications, and the more likely that the Commission would be involved in following-up (Comm\#2; Comm\#5). The "big discussions" between the EEAS and the Commission during the Communication drafting process were precisely on whether the Strategy should be military/security-oriented or cross-sectoral (EEAS\#1; EEAS\#3; Comm\#2; Comm\#4). Following the 2010 Council Conclusion, the EEAS suggested to focus on developing a military-oriented strategy, which the Commission opposed: "We didn't see the added value" and therefore "we stopped the process" (Comm\#4). Also according to the EEAS, it "came to a standstill [...] Because it is absolutely not possible to do it without the Commission [...] Sometimes I joke that [...] if you read an American maritime security strategy, it is about the employment and deployment of carrier battle groups. If you read the European maritime security strategy, it is all about keeping the Commission on board" (EEAS\#1).

When the EEAS re-started the process in 2012, it was from the perspective of developing a cross-sectoral strategy. However, while the Commission's bargaining tactics placed the cross-sectoral approach on the preparation table, it also had to convince the EEAS to endorse this in the Communication. And in line with the expert arguments hypothesis, the Commission convinced the EEAS with expert-based argumentation: "A European security strategy without the involvement of the Commission is not worth anything because [...] you would devise the complete wrong instrument for a type of problem that is of a completely different nature...you can say now we have reconsidered and have said well [...] our approach to maritime security needs to be comprehensive. This first attempt was not good enough" (EEAS\#1. Also EEAS\#2; EEAS\#3). When presented with the Commission's suggestion, the EEAS "got very interested [...] they saw the benefit of linking it to the integrated maritime policy" (Comm\#4). Thus, the cross-sectoral approach the member states adopted later was "a necessary and logical conclusion of our analysis" (EEAS\#1).

Second, when successfully reframing the EUMSS's scope, the Commission activated its role as an expert authority in interlinked Community areas. Eleven DGs contributed directly to the Communication based on their sectoral skills and knowledge: DG MOVE adding text on port and ship security, DG DEV on development issues, and DG Taxud on surveillance etc. (Comm\#2; Comm\#3; Comm\#5; EEAS\#1; EEAS\#3). Interestingly, lending support to the expert authority hypothesis, both Commission and EEAS interviewees said that all DGs' text suggestions were incorporated into the Communication directly, without any discussions or objections. This suggests that, after having agreed to a crosssectoral strategy, DG proposals were automatically incorporated precisely because they were the recognised experts on these issues (Comm\#1-\#5; EEAS\#1-\#3). The following quote from a Commission official immediately prior to the Communication's release is telling: "Discussions between the DGs and in the meetings and with the EEAS have not been so much on the content because the text from the different DGs is taken in directly [into the Communication]" (Comm\#2).

Following the Communication's publication, the Commission also drew on its expert authority to influence the "Friends of the Presidency" Group's discussions in preparing the June Council meeting. Here, the Greek Presidency introduced two substantial changes: reducing the number of actions and strengthening focus on security and defence (authors' copy). In the final Strategy, however, all but the actions suggesting concrete legislation were re-introduced. During these meetings, the Commission spoke and proposed amendments. According to national delegates, the Commission successfully proposed amendments because these amendments were seen as convincing (NatDel\#8; NatDel\#9). Most importantly, however, the Commission's attempts to reintroduce issues succeeded as a result of member states wanting to focus on other issues. Since the member states' discussions concentrated on "more important" nationally sensitive areas such as maritime surveillance, defence capabilities and NATO references, they had little interest in debating Commission proposals linked to existing Community areas. This resulted in most of the Commission's suggestions being kept in the EUMSS, and "this gives the Commission a lot of influence" (NatDel\#8). To sum up: the Commission's influence appears to be linked to its ability to convince the EEAS to initially accept its arguments for a cross-sectoral approach.

These observations point to the institutional circumvention hypothesis as being relevant to fully account for the Commission's influence in the EUMSS case: It gained its influence through working with the EEAS, as well as with the Greek presidency during May and June 2014. During the Communication preparation process, both EEAS and the Commission consulted member states informally (Comm\#5; EEAS\#1; EEAS\#3; NatDel\#2), anticipating that "every big country has particular interests" (Comm\#4; EEAS\#3). However, our interviewees revealed that "the EEAS and the Commission have been left to themselves" to decide the content (Comm\#3; Comm\#4). "The member states have not been involved so much" (Comm\#4). Indeed, only when the Communication was published did the 
PSC and the CSFP decision-making machinery start, with the member states' ambassadors "complain[ing] that you did not consult us" (Comm\#4).

According to national delegates, "this whole idea of joint communications, that is problematic for the member states, because...member states are not involved in the drafting [...] So that is a mixed blessing, because on the one hand they see the advantage of bringing in the Commission, sort of this joint communication, on the other hand they don't have control over it" (NatDel\#4). After the Communication's publication, the Commission worked very closely with bureaucrats from the Greek Presidency to prepare texts for the "Friends of the Presidency" meetings (Comm\#4; NatDel\#8; NatDel\#9). One of the authors also observed that the Commission sought to influence national bureaucrats in between the "Friends of the Presidency"/PSC meetings (Observations May 2014). To do so, the Commission again drew on its expert knowledge, approaching bureaucrats working in similar fields and trying to convince them to persuade their governments to support particular issues in the Communication (Observations May 2014).

Lastly, the Commission influenced the EUMSS through its institutional "know-how". Specifically, the EEAS followed "the Commission's modus operandi" (EEAS\#3; EEAS\#1; Comm\#4-\#5) because it lacked an established institutional procedure to lead the EUMSS process. According to a Commission interviewee, the member states "created an EEAS without defining how it should function...There is no proper road map leading to the strategy, no developed procedure" (Comm\#2). "It took some time to ripen... with the postLisbon world" (EEAS\#3). While there was an initial "lack of trust" between the two institutions (Comm\#5), an EEAS interviewee explained that "because you cannot keep doing these informal consultations, at some moment in time you need formal mechanisms, a formal structure, and that is what we have designed and created" (EEAS\#1). Thus, even if joint communications fall under the CSDP intergovernmental framework, they follow the "normal" Community approach in practice: "From an institutional perspective, this will be very productive. Now we have a framework, a structure on how to work in the future" (Comm\#3).

\section{The Case of External Migration: EU Mobility Partnerships}

Migration policy is an established issue area in European cooperation. Ever since the member states decided to realise the "free movement of labour" by removing internal border controls, the strengthening of their common external borders was considered an essential corollary (Geddes, 2008). Hence, through successive treaty revisions, from Maastricht to the Lisbon Treaty, we see that migration has moved from "an area of common interests" for the member states to a "com- munitarised policy area". This is now generally understood to mean that the central institutions-i.e., the Commission, the European Parliament, and the Court of Justice-possess their "ordinary" regulatory competence (Council of the European Union, 2012). We chose the "external dimension" of European migration cooperation as a case study because it is an exception to this "communitarisation" trend.

Institutional and legal innovations in European migration policy cooperation, according to several observers, are not uncommon (Chou, 2009; Peers, 2000; van Selm, 2002). In the main, these "exceptions" are meant to accommodate the different national preferences on certain migration issues, notably labour migration, and to allow the member states to retain decision-making powers in their hands. Hence, even though migration policy cooperation is said to be "communitarised", we observe that "the right of Member States to determine volumes of admission of third-country nationals" is not to be compromised (Council of the European Union, 2012). Put simply, European cooperation on selected migration issues, if and when it occurs, would be intergovernmental. Below, we investigate an instance of intergovernmental migration cooperationthe EU mobility partnerships-to consider whether, and, if so, how, the Commission influences its decisionmaking through expertise.

Similar to EU's military operations, EU mobility partnerships are ad hoc, voluntary, and involve only those member states and partner third countries interested in pursuing closer migration cooperation. It is a unique migration instrument that belongs to the EU's external policies and, hence, the decision-making and operational rules governing that cooperation are to apply. It is useful to note that the origin of EU mobility partnerships stems from the Union's initial failure to adopt a Council directive by the end of the Tampere period (i.e., 2004) that would regulate the entry and residence of migrants for employment purposes. Noting this in 2006, and wanting to promote the "Global Approach to Migration (and Mobility)" (GAMM), the European Council invited the Commission to propose "how to better organize and inform about the various forms of legal movement between the EU and third countries" (European Commission, 2007, p. 2). In response, the Commission launched the EU mobility partnership in 2007 as a "new instrument" for external migration cooperation.

To date, the EU has signed seven mobility partnerships: with Cape Verde and Moldova in May 2008; Georgia (November 2009); Armenia (October 2011); Morocco (June 2013); Azerbaijan (December 2013); and Tunisia (March 2014) (European Commission, 2014 , p. 2). The EU mobility partnership is now the main instrument with which the Union engages with the Arab Spring countries in the migration sector. Given the overall trend towards "communitarisation" in this sector, this turn towards preferring intergovernmental 
cooperation and its successful expansion is fascinating. Indeed, it allows us to approach the role of Commission expertise, as well as inter-institutional dynamics more generally, from another angle: How and why did the member states fail to prevent the European executive from influencing intergovernmental processes? This question points to an underlying assumption about the "nature" of intergovernmental cooperation in European integration, namely, that it involves only national officials representing the participating member states at the "expense" of central institutions. As briefly noted at the beginning, there are a growing number of studies pointing to the Commission's increased influence in areas where it lacks or has limited competence. As we shall show below, its cross-sectoral expert knowledge is a crucial contributing factor to this development.

To start, there is evidence to confirm that the participating member states did not seek to exclude the Commission from the preparation, negotiation, and even the implementation of the mobility partnerships. Put differently, the member states "failed" to prevent the Commission because they never intended to do so in the first place. Indeed, the Commission has been the coordinator in this process. In interviews with Frontex officials, Djupedal (2011, p. 40) described the Commission as the "node" around which the implementation of EU-Cape Verde mobility partnership revolved: "we have regular meetings in Brussels, and we are all invited by the Commission. We discuss proposals [...] and the progress of the mobility partnership is measured [by] the Commission task force". Confirming that the Commission's involvement was welcomed, we find that it is even a signatory to the EU mobility partnerships and some of its proposals were also included (see Annex of all mobility partnerships). This led an official from the legal service of the Council's GeneralSecretariat to remark that the EU mobility partnership is legally "experimental" because the Commission also signs (quoted in Chou \& Gibert, 2012, p. 210). Others have noted its "non-binding nature" (House of Lords, 2012, p. 53) and "soft legal nature" (Van Vooren, 2012, p. 210), pointing to the "flexibility" that EU mobility partnership offers to the participating states.

The inclusion of the Commission in the EU mobility partnerships did not mean that the member states were not cautious or inattentive to its role or influence. On the contrary, Reslow (2012, p. 228) argues that the Commission was very much a "Limited Policy Initiator". This is because the EU mobility partnerships were designed to consider the possibility of labour mobility between participating member states and third countries. According to her, "Member states will indicate when the Commission is going too far in its proposals, for instance by incorporating issues which they see as falling under their competence, or which are particularly sensitive" (Reslow, 2012, p. 229). This perspective, however, does not explain the Commission's active role in this process. Indeed, Reslow (2012, p. 229) admits that it was the Commission that "suggested potential partner countries, gauged the level of interest of the member states, conducted exploratory talks with partner countries, and had a coordinating role in the negotiations between the member states and partner countries". So why is the Commission a central actor in the preparations and negotiations for EU mobility partnerships?

Our findings lend support to the expert authority hypothesis in two ways. First, the Commission has the cross-sectoral knowledge of the three issues at the heart of mobility partnerships: development (i.e., capacity-building, training), migration and security (border management, trafficking, asylum, return, labour market access, visa facilitation). At the departmentallevel, the corresponding Commission DGs involved at the time included Home (lead DG), Development, and Aid (Djupedal, 2011, p. 39). Similar to its role in drafting the EUMSS, the Commission also prepared the GAMM, which outlined the mobility partnerships' operational goals, and was responsible for GAMM's subsequent reporting (European Commission, 2011). Unlike the EUMSS, however, the Commission was not responsible for widening the scope of GAMM, which strategically linked development with migration and security. According to Chou (2012b, pp. 22-24), EU high-level discussions concerning how to operationalise the "migration-development nexus" for achieving security goals have been on-going since the late 1990s (cf. Lavenex \& Kunz, 2008). By tasking the Commission to explore ways of implementing the GAMM, and, in so doing, acknowledging its expert authority on these issues, the European Council also paved the way for its inclusion in the intergovernmental decision-making.

Second, more than some participating member states, the Commission has the organisational "knowhow" and resources to make negotiating and implementing the mobility partnerships possible. In terms of coordination, DG Home acted as the nerve centre in Brussels with EU delegations at the capitals of participating third countries (Dakar, Praia) its nerve extension (Djupedal, 2011, pp. 39-42). According to our Commission interviewee (Comm\#6), EU delegations prepared the meetings in partner third countries, while DG Home, liaising with their missions in Brussels, would oversee those meetings. Similar to the case of Atalan$t a$, the Commission's considerable tools in the development sector (i.e., aid and field knowledge) were crucial: They enticed partner third countries to the talks (Chou \& Gibert, 2012), and provided the specialist knowledge on the grounds. DG Development officials accompanied DG Home official regularly at the start of negotiations (Comm\#6; Comm\#7; Comm\#8). We found that the Commission did not use development aid as a bargaining tool to insert itself at the negotiation table; it also did not circumvent or convinced the member states with expert arguments. Several DG Home inter- 
viewees (Comm\#6; Comm\#9) revealed what the member states appreciated the most: Regularly updated scoreboard showing not only progress, but also those responsible for task implementation (i.e., which member state, EU agency, third country ministry or agency, or the Commission). To sum up, these attributes made the Commission a "one-stop-shop" for the member states when they sought a reliable coordinator to assist in these intergovernmental arrangements.

Finally, examining the failed negotiations with Senegal to conclude an EU mobility partnership offers another insight concerning the Commission's role in intergovernmental decision processes. The Commission approached Cape Verde and Senegal at the same time, but suspended talks with the latter due to a lack of progress. According to Chou and Gibert (2012, p. 409), this failure can be attributed to a combination of factors, notably the "unfavourable cost-benefit calculus by the French and Senegalese parties to the negotiation" and "an unclear and awkward negotiating strategy on the part of the European Commission". They showed that France was not interested in an EU instrument overseeing its well-functioning bilateral migration cooperation with its former colony. Quoting a French interviewee in Dakar, Chou and Gibert (2012, p. 420) tell us that "France will be happy to take part in the mobility partnership if Senegal is willing" [...] but "France [...] does not wish to take the lead on this and will stay behind the EU'". It is France's unwillingness to openly oppose these talks that lead us to propose that the Commission has another function in intergovernmental discussions with third countries: it represents the Union in the absence of a united front. While this mobility partnership did not materialise, our findings showed that the Commission exercised considerable influence through its expertise during these intergovernmental decision processes.

\section{Conclusion}

This article set out to consider whether and, if so, how the Commission's expert knowledge contributed to accounting for empirical observations of its growing influence in intergovernmental policy-areas. We find that, indeed, the Commission's use of expertise captures much of its de facto influence in issue-areas where its competence remains formally limited. By distinguishing between two expertise-based hypotheses (expert authority and expert arguments), we are able to say more about how its expertise matters than the existing literature provides. Specifically, in several of our cases, the Commission used its expert arguments to influence the member states' and other actorsmost notably the EEAS'-positions on common policies. Most importantly, in all cases the Commission informed decision-making by successfully linking discussions to policy-areas where it possesses expert authority. This suggests that, despite the member states' attempts to formally maintain a division between "Community" and "intergovernmental" policies, this division is difficult to enforce in practice given the centrality of the Commission's expertise in informing the member states' subsequent policy decisions. This mutual reliance may be one of the "hidden" dynamics of European integration that helps us make sense of how and why European cooperation has intensified and deepened in sectors and on issue-areas at the heart of national sovereignty.

Our findings revealed that, while expertise accounts substantially for our empirical observations of growing Commission influence in formally intergovernmental EU policy-areas, bargaining tactics and institutional circumvention are also important. Our limited number of case studies suggests that these are fruitful avenues for further research before any generalisation can be made about Commission expertise in intergovernmental policy-areas. The EUMSS in particular is still a work in progress (in terms of implementation), so any conclusions about the "real" influence of the Commission would be premature at this stage. While our framework offers the first step for an improved understanding of the different functions of expertise in EU decisionmaking processes, we believe that, in particular, our expert arguments hypothesis can be usefully applied to investigate how transnational non-governmental actors may affect intergovernmental agreements and outcomes more generally. To sum up, this article suggests that it is the Commission's expert arguments and invoking of expert authority that have paved the way for how it can exercise its Treaty powers in intergovernmental and non-communitarised issue-areas.

\section{Acknowledgement}

We want to thank the editors, Åse Gornitzka and Cathrine Holst, as well as four anonymous reviewers for their valuable questions and comments that have improved this article. A previous version of this paper was presented at the ECPR General Conference in Bordeaux, 5-7 September 2013. We would like to thank all the panel participants for their helpful suggestions and Tom Delreaux for his comments and for organising the panel on "The Institutional Dimension of the EU's External Relations". Meng-Hsuan Chou wants to thank the School of Humanities and Social Sciences (Nanyang Technological University) and Marianne Riddervold the Norwegian Ministry of Defence for financing this research.

\section{Conflict of Interests}

The authors declare no conflict of interests.

\section{References}

Aggestam, L. (2006). Role Theory and European Foreign 
Policy. In O. Elgstrøm \& M. Smith (Eds.), The European Union's Roles in International Politics (pp. 1129). London: Routledge.

Barnett, M. N., \& Finnemore, M. (1999). The politics, power, and pathologies of international organizations. International Organization, 53(4), 699-732.

Barnett, M. N., \& Finnemore, M. (2004). Rules for the World. Ithaca: Cornell University Press.

Busch, P. O., \& Liese, A. (2014). A framework for a comparative analysis of expert authority of international public administrations. Paper presented at the 2014 ECPR Joint Sessions.

Checkel, J. T. (2001). Why comply? Social learning and European identity change. International Organization, 55(3), 553-588.

Chou, M. H. (2009). The European security agenda and the "external dimension" of EU asylum and migration cooperation. Perspectives on European Society and Politics, 10(4), 541-559.

Chou, M. H. (2012a). Constructing an internal market for research through sectoral and lateral strategies. Journal of European Public Policy, 19(7), 1052-1070.

Chou, M. H. (2012b). EU Mobility Partnerships and Gender. In R. A. Sollund (Ed.), Transnational Migration, Gender and Rights (pp. 11-31). Bingley: Emerald.

Chou, M. H., \& Gibert, M. (2012). The EU-Senegal mobility partnership. Journal of Contemporary European Research, 8(4), 409-426.

Copeland, P., \& James, S. (2014). Policy windows, ambiguity and Commission entrepreneurship. Journal of European Public Policy, 21(1), 1-26.

Council of the European Union. (2008). Council joint action 2008/851/CFSP of 10 november 2008: On a European Union military operation to contribute to the deterrence, prevention and repression of acts of piracy and armed robbery off the somali coast. Official Journal of the European Union, L 301(12 November 2008), 33-37.

Council of the European Union (2010). Council conclusions on a Maritime security strategy 309th Foreign Affairs Council meeting. Luxembourg, 26 April 2010.

Council of the European Union (2012). Consolidated Versions of the Treaty on European Union and the Treaty on the Functioning of the European Union and the Charter of Fundamental Rights of the European Union (6655/7/08 REV7). Luxembourg: Publications Office of the European Union.

Cross, M. (2010). Epistemic Communities and the Transnational Network Approach to EU Diplomacy and Security Policy. In C. M. Costantinou \& J. Derian (Eds.), Sustainable Diplomacies (pp. 192-212). Houndmills: Palgrave Macmillan.

Dahl, R. (1957). The concept of power. Behavioral Science, 2(3), 201-215.

Deitelhoff, N. (2009). The discursive process of legalization. International Organization, 63(1), 33-65.

Djupedal, A. K. (2011). Recent Developments in the EU
Migration Management Policy. Master Thesis, Department of Political Science, University of Oslo.

Egeberg, M. (2006). Multilevel Union Administration. The Transformation of Executive Politics in Europe. Houndmills: Palgrave Macmillan.

Elgstrøm, O., \& Smith, M. (2006). The European Union's Roles in Internationanl Politics. London: Routledge.

Eliaeson, S. (2002). MaxWeber's Methodologies. Oxford and Malden: Blackwell Publishers.

Eriksen, E. O. (2005). Reflexive Integration in Europe. In E. O. Eriksen (Ed.), Making the European Polity. Reflexive Integration in the EU (pp. 9-29). London: Routledge.

Eriksen, E. O., \& Fossum, J. E. (2000). Democracy in the European Union: Integration through Deliberation? London: Routledge.

European Commission. (2007). Communication on Circular Migration and Mobility Partnerships Between the European Union and Third Countries (COM(2007)248 final). Brussels, Belgium: European Commission.

European Commission. (2011). Communication on the Global Approach to Migration and Mobility. (COM(2011)743 final). Brussels, Belgium: European Commission.

European Commission. (2014). Annexes to the Report on the implementation of the Global Approach to Migration and Mobility 2012-2013. (COM(2014)96 final). Brussels, Belgium: European Commission.

European Council. (2013) European Council 19/20 December 2013 Conclusions, Brussels, 20 December 2013, EUCO217/13. Brussels, Belgium: European Council.

Geddes, A. (2008). Immigration and European integration: Beyond fortress Europe? Manchester: Manchester University Press.

Gornitzka, Å. (2009). Networking Administration in Areas of National Sensitivity. In A. Amaral, P. Maassen, C. Musselin \& G. Neave (Eds.), European Integration and the Governance of Higher Education and Research (pp. 109-131). Dordrecht: Springer.

Haas, P. M. (1992). Introduction: Epistemic communities and international policy coordination. International Organization, 46(1), 1-35.

Hooghe, L. (2001). The European Commission and the Integration of Europe. Cambridge: Cambridge University Press.

Hooghe, L. (2005). Several roads lead to international norms, but few via international socialization. International Organization, 59(4), 861-898.

House of Lords. (2012). The EU's Global Approach to Migration and Mobility. Report from the European Union Committee, $8^{\text {th }}$ Report of Session 2012-2013 (HL Paper 91). London: The Stationery Office Limited.

Joerges, C., \& Neyer, J. (1997). From intergovernmental bargaining to deliberative political processes. European Law Journal, 3, 273-299.

Jørgensen, K. E., Oberthür, S., \& Shahin, J. (2011). 
Introduction: Assessing the EU's performance in international institutions-Conceptual framework and core findings. Journal of European Integration, 33(6), 599-620.

Lavenex, S., \& Kunz, R. (2008). The migrationdevelopment nexus in EU external relations. Journal of European Integration, 30(3), 439-457.

Lewis, J. (2011). EU Policy on the Iraq War and Its Aftermath. In D. C. Thomas (Ed.), Making EU Foreign Policy (pp. 10-28). Houndmills: Palgrave Macmillan.

March, J. G., \& Olsen, J. P. (1998). The institutional dynamics of international political orders. International Organization, 52(4), 943-969.

March, J. G., \& Olsen J. P. (2006). The Logic of Appropriateness. In M. Moran, M. Rein \& R. E. Goodin (Eds.), The Oxford Handbook of Public Policy (pp. 689-708). Oxford: OUP.

Martens, M. (2008). Administrative integration through the back door? Journal of European Integration, 30(5), 635-651.

Merket, H. (2012). The European External Action Service and the nexus between CFSP/CSDP and development cooperation. European Union foreign Affairs Review, 17(4), 625-652.

Olsen, J. P. (2009). Change and continuity: An institutional approach to institutions of democratic government. European Political Science Review, 1(1), 3-32.

Peers, S. (2000). EU Justice and Home Affairs Law. London: Longman.

Pollack, M. A. (1997). Delegation, agency and agenda setting in the European Community. International Organization, 51(1), 99-134.

Reslow, N. (2012). Deciding on EU external migration policy. Journal of European Integration, 34(3), 223-239.

Riddervold, M. (2011). From reason-giving to collective action: Argument-based learning and European integration. Cooperation and Conflict, 46(4), 563-580.

Riddervold, M. (2014). Different threat, different response. EU and NATO in the fight against Somali piracy. European Security. doi: 10.1080/09662839. 2014.937337.

Riddervold, M. (2015). (Not) in the hands of the member states. How the European Commission influences the CSDP. Under review.

Riddervold, M., \& Sjursen, H. (2012). Playing into the Hands of the Commission? In O. Costa \& K. E. Jørgensen (Eds.), The Influence of International Institutions on the EU. London: Palgrave Macmillan.

Risse, T. (2000). Let's argue! Communicative action in world politics. International Organization, 54(1), 1-39.

Rittberger, B. (2012). Institutionalizing representative democracy in the European Union. Journal of Common Market Studies, 50(S1), 18-37.

Rosén, G. (2014). EU confidential: The European Parliament's involvement in EU security and defence policy. Journal of Common Market Studies, in press. doi:10.1111/jcms.12154

Schmidt S. K. (2001). Only an agenda setter? The European Commission's power over the Council of Ministers. European Union Politics, 1(1), 37-61.

Sjursen, H. (2004). Changes to European security in a communicative perspective. Cooperation and Conflict, 39(2), 107-128.

Tallberg, J. (2008). Bargaining power in the European Council. Journal of Common Market Studies, 46(3), 685-708.

Thym, D. (2011). Holding Europe's CFSP/CSDP executive to account in the age of the Lisbon Treaty. Serie Union Europea, 53.

van Selm, J. (2002). Immigration and Asylum or Foreign Policy. In S. Lavenex \& E. M. Uçarer (Eds.), Migration and externalities of European Integration (pp. 143-160). Oxford: Lexington Books.

Van Vooren, B. (2012). EU External Relations Law and the European Neighbourhood Policy. Abingdon: Routledge.

\section{About the Authors}

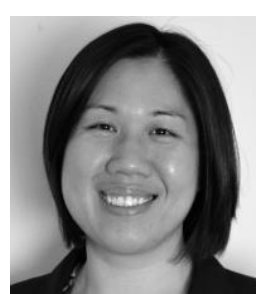

\section{Dr. Meng-Hsuan Chou}

Dr. Meng-Hsuan Chou is Nanyang Assistant Professor in Public Policy and Global Affairs Programme at Nanyang Technological University (NTU), Singapore.

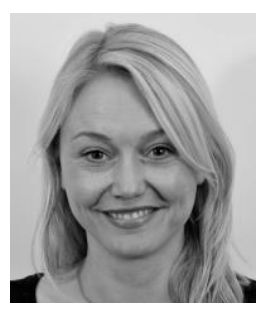

\section{Dr. Marianne Riddervold}

Dr. Marianne Riddervold is a post-doctoral fellow at ARENA-Centre for European Studies, at the University of Oslo, Norway. 


\section{Appendix: List of interviewees}

Comm\#1: Commission official 26/2-2014

Comm\#2: Commission official 26/2-2014

Comm\#3: Commission official 27/2-2014

Comm\#4: Commission official 11/3-2014

Comm\#5: Commission official 27/2-2014

Comm\#6: Commission official 15/9-2009

Comm\#7: Commission official 23/9-2009

Comm\#8: Commission official 23/9-2009

Comm\#9: Commission official 17/9-2009

EEAS\# 1: European External Action Service official 13/2-2014

EEAS\# 2: European External Action Service official 19/6-2014

EEAS\#3: European External Action Service official 27/2-2014

EP\#1: European Parliament advisor 17/6-2013

EUSPHoA\#1: Official at EU Special representative for the Horn of Africa, European External Action Service 17/2-2014

IMO\#1: National representative, the IMO 21/6-2010

NatDel\#1: Official at Permanent national delegation to the EU 19/6-2013

NatDel\#2: Official at Permanent national delegation to the EU 19/6-2013

NatDel\#3: Official at Permanent national delegation to the EU 19/6-2013

NatDe\#4: Official at Permanent national delegation to the EU 19/6-2013

NatDel\#5: Official at Permanent national delegation to the EU 18/6-2013

NatDel\#6: Official at Permanent national delegation to the EU 4/6-2013

NatDel\#7: Official at Permanent national delegation to the EU 23/5-2013

NatDel\#8: Official at Permanent national delegation to the EU 28/5-2014

NatDel\#9: Official at Permanent national delegation to the EU 3/6-2014

NATO \#1: NATO military staff 17/6-2010

NATO\#2: NATO military staff, 27/8-2010

NATO\#3: NATO military staff $17 / 6-2013$

NATO\#4: NATO military staff 24/6-2010

NATO\#5: NATO military staff 20/6-2013

OpCen\#1: Official at EU operations center 17/6-2013

OpCen\#2: Official at EU operations center 17/6-2013 